\title{
The geometric parameters of plants on the spur dykes in a selected section of the Odra River
}

\author{
Magda Hudak ${ }^{1, *}$ \\ ${ }^{1}$ University of Zielona Góra, Faculty of Civil Engineering, Architecture and Environmental \\ Engineering
}

\begin{abstract}
Spur dykes are structures for regulating rivers. They are designed for medium water levels, when spur dyke tops are above the water surface. In the central section of the Odra River the water level is changeable, and the spur dykes work in different hydrological conditions: as non-submerged and submerged. Correct recognition of the plant structure growing on the spur dykes is of great importance in the context of the subsequent allocation of its measure related to the hydraulic action, among others coefficients of resistance of plant zones and refers mainly to grasses. In hydraulic calculations, it is required to determine the value of flow resistance coefficients. In such a departure, the flow is omitted in the area occupied by vegetation. Therefore, it is necessary to know the quantitative characteristics of overgrowth. Vegetation should be presented in the form of a model reflecting the impact of plants growing on the spur dykes and their impact on the water flow conditions in the river. Literature data are not very numerous and are still awake unsatisfied. The paper presents the results of research on the density of vegetation on the Odra River in the Nowa Sól region.
\end{abstract}

\section{Introduction}

Spur dykes, also known as wing dykes or groynes, are structures used to regulate rivers, an are situated perpendicularly to the banks of a river. Their primary task is to protect the river banks and direct the current.

Spur dykes, as hydrotechnical objects, usually form a system of structures, between which there are inter-spur dyke areas, or "basins". A single spur dyke is a dam perpendicular to the current, made of stones and soil, covered with a fascine mattress and secured with stones. Newly built spur dykes are not covered with any vegetation and their surface is made of stones. The older the spur dyke is, the thicker the vegetation on it.

Since the water level in rivers changes, spur dykes are designed for medium conditions, when their tops are above the water level, i.e. they are not submerged. Then, the water moves in the main canal, and the water exchange between the main canal and the inter-spur dyke area is small. In the area of the spur dyke heads, a significant increase in water flow velocity can be observed; moreover, vortices moving downstream can be observed. In the areas between the spur dykes, the movement of water is much slower in comparison with

\footnotetext{
*Corresponding author: m.hudak@,iis.uz.zgora.pl
} 
the rest of the river bed, which means that debris is deposited in these areas. The areas between spur dykes become places with abundant vegetation.

However, as the water level rises, the spur dykes are submerged, which creates a new regime for the work of the structure. The highest water flow velocity is still observed in the main canal but the spur dykes are an obstacle and slow down the flow of water in this part of the canal, which may be important during floods [1].

In hydraulic calculations of natural river beds it is necessary to take into account the impact of vegetation growing in the river bed, its banks or floodplains on the water flow conditions. The hydraulic impact of plants largely depends on both the hydrodynamic parameters of the stream and the plant species, their biomechanical properties and the geometric characteristics of a particular plant community. These features can be taken into account when describing vegetation with the so-called parameters of plant communities [2].

Determination of the parameters of a single plant, such as: height, diameter, number and length of plant branches does not allow unambiguously determining its impact on water traffic conditions. Only the examination of these parameters for a larger plant cluster, in statistical terms, allows us to refer such results to changes in hydraulic parameters during the freshet [3]. In the mathematical description of plant communities, it is necessary to assign a certain measure to plant density. This measure can be, for example, the volumetric concentration of plants $\rho_{R}$, the vegetation density $D_{p}$, the porosity of the plant zone $p$, etc. Sometimes this is not a single parameter but a complex calculation procedure [4].

In the current studies, medium and high vegetation was dealt with; however, low vegetation was neglected. It was the subject of research only in terms of flexibility.

\section{Objective of the paper}

The objective of this paper is to present the representative geometrical parameters of the plants on the spur dykes in a selected section of the Odra River. Literature analysis shows that the research carried out so far has mainly dealt with the vegetation in riverbeds $[5,6$, $7]$, and in the inter-levee zone $[8,9]$.

Because of the frequent occurrence of floods and the possibility of reactivation of the Odra Waterway (OW), a qualitative analysis of the impact of the plants growing on the spur dykes on the hydraulic system of the river bed is very interesting and valuable.

\section{Research materials and methodology}

\subsection{Characteristics of the research area}

The research dealt with the spur dykes in a section of the free-flowing Odra River $(427 \mathrm{~km}+000 \div 428+000 \mathrm{~km})$ - a total of 23 spurs dykes. Geographically, this area is located in the Barucko-Głogowska Ice Marginal Valley, in the Nowa Sól Odra River Gorge.

\subsection{Measurements of plant parameters}

The measurements of plant parameters consisted in:

- the determination of - due to the geometric dimensions - a representative for each community, a group of plants;

- determining the height and diameter characteristic of the plant;

- determining the space between the stems in the direction of the water flow and perpendicularly to the direction of the water flow. 
The measurements were carried out using a meter stick and a vernier calliper with an accuracy of $\pm 0,1 \mathrm{~mm}$. Three control areas with dimensions of $1.0 \times 1.0 \mathrm{~m}$ were determined on each of the groynes and detailed quantitative measurements were made. Moreover, the measurements of land cover (spur) and identitification of the parent plant species.

The concentration of plants was determined with the volumetric method as $1.5 \%$ on the basis of the samples taken.

\subsection{Vegetation parameters}

After literature analysis the following parameters of plant communities were specified:

- plant density $D_{p}[10]$,

- hydraulically active plant density [11]

$$
D_{v}=\frac{\sum\left(c_{w, j} \cdot A_{R, j}\right)}{L b}[-]
$$

where: $A_{r, j}$ - the water flow area of the $j^{\text {th }}$ plant element, i.e. $A_{r, j}=d_{p} \cdot h\left[m^{2}\right]$,

$d_{p}$ - the diameter representative of a particular plant group; $\mathrm{m}$,

$c_{w}$ - the plant resistance coefficient (Fig. 1),

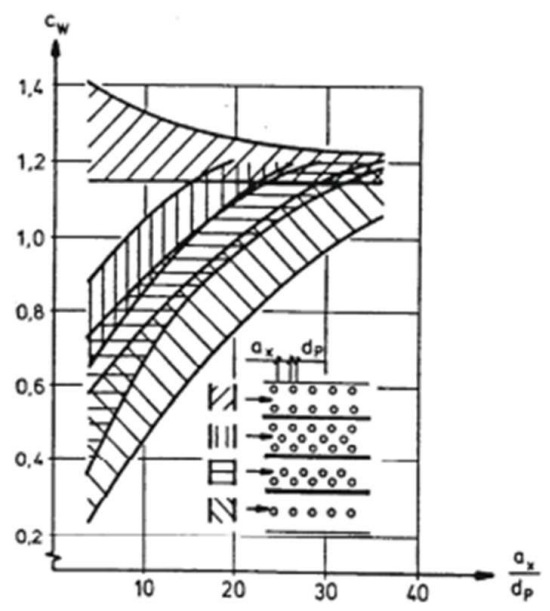

Fig. 1. The dependence of the resistance coefficient on the space between the plants in the direction of the water flow ax and the diameter of the plants $d_{p}$ [2].

$h$ - the depth of the submerged parts of the plants; $m$.

$b$ - the width of the plant zone; $\mathrm{m}$,

$L$ - the length of the plant zone; $m$.

- the number of the plant area $\varepsilon_{p}[12,13]$

$$
\varepsilon_{p}=\frac{\sum A_{R, p}}{L b}[-]
$$

where: $A_{r, p}$ - the area of the cross-section of the $\mathrm{j}^{\text {th }}$ plant element

- the number of the plant volume $\rho_{R}[12]$

$$
\rho_{R}=\frac{\sum V_{R, j}}{b h L} 100 \%
$$


where: $V_{R, j}$ - the volume of the submerged parts of the plants; $\mathrm{m}^{3}$.

- the extent of blockage of the water flow cross-section [2]

$$
\delta=\frac{\sum A_{R, j}}{A_{v}}[-]
$$

where: $A_{v}$ - the area of the plant zone (vertical cross-section); $\mathrm{m}^{2}$.

It was assumed in the calculations that the submergence depth of the plants $h=0.3 \mathrm{~m}$, with an average plant height of $1.1 \mathrm{~m}$, i.e. the height of the plants is greater than the submergence depth, the water flows around the stems. Chalfen's, Molski's and Tymiński's [14] studies have shown that since the filling of approx. $0.20 \mathrm{~m}$ the velocities decrease with increasing filling, because the flow resistance of a single element increases, as well as the number of these elements. Therefore, the vertical geometric variability of plants is not taken into account in the calculations.

\section{Research results}

\subsection{Measurements of plant parameters}

As a result of field research, the representative plant species forming the spur dyke vegetation in the Odra River section under analysis were identified. These are: Phalaris arundinacea, Urtica dioica L. and Phragmites Australis. The plant development in the discussed area shows in Photo 1.

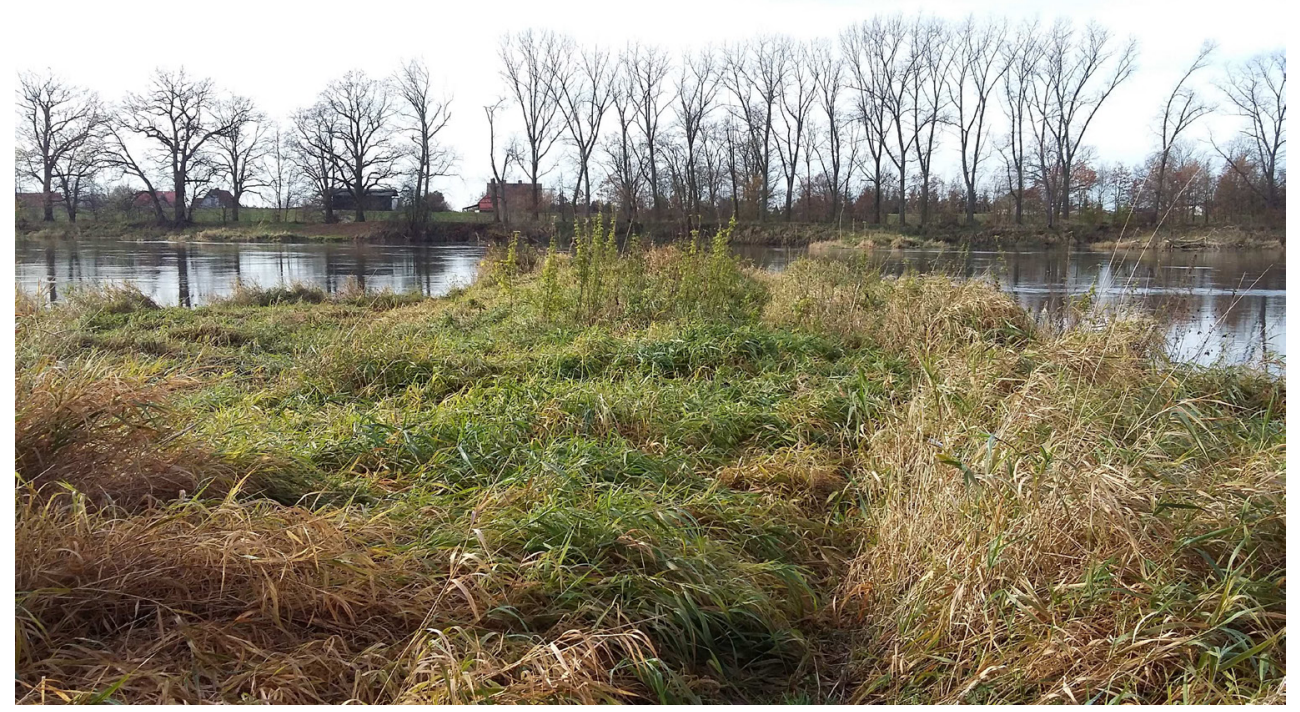

Photo 1. The plants (Phalaris arundinacea) on the spur dyke located on the Odra River $(427+600 \mathrm{~km})$.

It was found that on all analyzed spurs, the dominant species is reed canary (Phalaris arundinacea), which forms single-species communities on the ground, where the accumulation process of organic material is intense. On unstable, strongly hydrated ground it creates powerful, creeping roots and rhizomes [15]. In addition, the fllowing clusters have been observed:

- Urtica dioica L. - on 19 spurs, 
- Phragmites Australis - on 2 spurs.

When analyzing vegetation cover, it should be stated that a representative spur in $78 \%$ is built up with vegetation, including:

- in $62 \%$ it is covered Phalaris arundinacea,

- in $13 \%$ it is covered Urtica dioica L.,

- in 3\% it is covered Phragmites Australis.

A representative plant diameter was also determined $-d_{p}=0.003 \mathrm{~m}$ and height $-H=$ $1.1 \mathrm{~m}$. The space between the stems in the direction of the water flow was determined $-a_{y}=$ $0.04 \mathrm{~m}$ and perpendicularly to the water flow $-a_{x}=0.04 \mathrm{~m}$.

Measurement uncertainty is measured by standard uncertainty. It has been estimated by the type B method and amounts to: for the diameter of the plant $u(\mathrm{~mm})=5.8 \cdot 10^{-3} \mathrm{~mm}$, while for the plant height $u(\mathrm{~mm})=5,8 \cdot 10^{-2} \mathrm{~mm}$.

\subsection{Parameters of the plant cover}

Detailed quantitative measurements showed that the median plant density $D_{p}$ is 620 plants $\cdot \mathrm{m}^{-2}$.

The hydraulically active density $D_{v}$, which takes into account the spatial layout of the plants, was calculated using the formula (1) and the medium value is 0.72 .

The number of plant surface $\varepsilon_{p}$ was calculated using the formula (2). It expresses the ratio between the total area of horizontal cross-sections of plant elements and the total area of the plant cover. The medium value it is $\varepsilon_{p}=0.006$.

The number of plant volume $\rho_{R}$, which denotes the share of the submerged plant parts in the volume of the plant community, takes into account the share of the submerged plant parts in the total volume of the plant community. It was calculated using the formula (3) and for characteristic cover it is $\rho_{R}=0.57 \%$.

The extent of blockage of the water flow cross-section $\delta$ determines the share of the water flow surface of plant elements in the water flow section of the plant zone. It was calculated using the formula (4) and for characteristic cover it is $\delta=63.4$.

\section{Summary and conclusions}

The analysis of plant cover on the discussed section of the Odra River $(427 \mathrm{~km}+000 \div 428$ $+000 \mathrm{~km})$ - a total of 23 spurs (12 spurs on the left riverside and 11 spurs on the right riverside) showed that the representative plant species are Phalaris arundinacea, Urtica dioica L. and Phragmites Australis. Characteristic plant development constitutes $78 \%$ of the spur area, of which $62 \%$ is Phalaris arundinacea, 13\% - Urtica dioica L., and 3\% Phragmites Australis.

The results of field research of the plants on the spur dykes located on the discussed section of the river presented in this article showed a high extent of blockage of the water flow cross-section $\delta=63.4$ and high hydraulically active plant density $D_{v}=0.72$, but a low number of plant area $\varepsilon_{p}$, which is 0.006 , and also a low number of plant volume $\rho_{R}=0.57$ $\%$.

Such high values of the parameters characterizing plant density occur simultaneously with small values of the parameters describing the number of plant elements forming the plant zone. This means that the geometrical structure of the plant zone under research, consisting mainly of grassy plants, is spatially developed.

It should be noted that the plant submergence depth adopted for the calculations $(h=0.3$ m) does not take into account the vertical geometric variability of the plants. The calculations assume that above this height leaves grow from a single stem, which 
significantly changes the structure of the plant and affects, among other things, the extent of blockage of the water flow cross-section or the number of plant area.

It is worth noting that the importance of correct diagnosis of the structure of plants growing on spurs is very important in the context of the subsequent assignment of measurement associated with the impact of hydraulic, for example, The coefficients of resistance for the vegetation zones.

\section{References}

1. M. Robakiewicz, I. and E. R. A., Wyd. PAN, 4, (2006)

2. T. Tymiński, I. and E. R. A., Wyd. PAN, 7, (2008)

3. J. Florek, Wplyw roślinności terenu zalewowego na przepustowość i stabilność koryta wielkiej wody. I. and E. R. A., Wyd. PAN, 4/2 (2006)

4. T. Kałuża, XVI Ogól. Sz. Hydr.. IBW PAN (1996)

5. J. Florek, Zesz. Nauk. AR, 18, (1998)

6. E.P. Querner, Przeplyw $w$ korycie o zwartym przekroju poprzecznym porośniętym roślinnościa wodna. Wyd. SGGW, „Hydrauliczne podstawy obliczania przepustowości koryt rzecznych" Warszawa (2003)

7. S. Petryk, G. Bosmajian, ASCE. J. Hydr. D., HY7, VII, 101, (1975)

A. Kozioł, J. Kubrak, Przeptyw wody $w$ korycie o złożonym przekroju poprzecznym z terenami zalewowymi porośniętymi drzewami. Wyd. SGGW. „Hydrauliczne podstawy obliczania przepustowości koryt rzecznych" Warszawa (2003)

8. T. Kałuża, T. Tymiński, I. and E. of R. A., Wyd. PAN, 8, (2010)

9. G.J. Klaassen, J. J. van der Zwaard, J. Hydr. Research, 12, (1974)

10. Rouvé et al., Hydraulische Probleme beim naturnahen Gewässerausbau. Deutsche Forschungsgemeinschaft, Forschungsbericht. VCH Verlagsgesellschaft Weinheim, (1987)

11. W. Kaiser, TH Darmstadt, 23, (1984)

12. M. Chalfen, T. Molski, T. Tymiński, I. and E. R. A., Wyd. PAN, 8, (2010)

13. Cz. Wysocki, P. Sikorski, Fitosocjologia stosowana $w$ ochronie $i$ ksztattowaniu krajobrazu. Wyd. SGGW. Warszawa (2009) 